\title{
Anthropogenic Organic Pollutants in Groundwater Increase Releases of Fe and Mn from Aquifer Sediments: Impacts of Pollution Degree, Mineral Content, and $\mathrm{pH}$
}

\author{
Yuanzheng Zhai $\mathbb{D}^{\mathrm{D}}$, Yifan Han, Xuelian Xia *, Xindai Li * $\mathbb{D}$, Hong Lu, Yanguo Teng and Jinsheng Wang \\ Engineering Research Center of Groundwater Pollution Control and Remediation of Ministry of Education of \\ China, College of Water Sciences, Beijing Normal University, Beijing 100875, China; diszyz@163.com (Y.Z.); \\ 201921470006@mail.bnu.edu.cn (Y.H.); 201931470035@mail.bnu.edu.cn (H.L.); teng1974@163.com (Y.T.); \\ wangjs@bnu.edu.cn (J.W.) \\ * Correspondence: xxl18811485804@163.com (X.X.); 1xzlxz5757@163.com (X.L.); Tel.: +86-188-1148-5804 (X.X.); \\ +86-010-58802736 (X.L.); Fax: +86-010-58802736 (X.L.)
}

check for updates

Citation: Zhai, Y.; Han, Y.; Xia, X.; Li, X.; Lu, H.; Teng, Y.; Wang, J. Anthropogenic Organic Pollutants in Groundwater Increase Releases of Fe and Mn from Aquifer Sediments: Impacts of Pollution Degree, Mineral Content, and pH. Water 2021, 13, 1920 https://doi.org/10.3390/w13141920

Academic Editor:

Alexander Yakirevich

Received: 10 June 2021

Accepted: 7 July 2021

Published: 12 July 2021

Publisher's Note: MDPI stays neutral with regard to jurisdictional claims in published maps and institutional affiliations.

Copyright: (c) 2021 by the authors. Licensee MDPI, Basel, Switzerland. This article is an open access article distributed under the terms and conditions of the Creative Commons Attribution (CC BY) license (https:// creativecommons.org/licenses/by/ $4.0 /)$.

\begin{abstract}
In many aquifers around the world, there exists the issue of abnormal concentrations of Fe and Mn in groundwater. Although it has been recognized that the main source of this issue is the release of Fe and $\mathrm{Mn}$ from aquifer sediments into groundwater under natural environmental conditions, there lacks enough reliable scientific evidence to illustrate whether the pollutants imported from anthropogenic activities, such as organics, can increase this natural release. On the basis of time series analysis and comparative analysis, the existence of an increasing effect was verified through laboratorial leaching test, and the impacts of aquatic chemical environment conditions, such as $\mathrm{pH}$, on the effect were also identified. The results showed that the increase of organics in groundwater made the release of $\mathrm{Fe}$ and $\mathrm{Mn}$ more thorough, which was favorable for the increase of groundwater concentrations of $\mathrm{Fe}$ and $\mathrm{Mn}$. The higher the contents of Fe- and Mn-bearing minerals in aquifer sediments, the higher the concentrations of $\mathrm{Fe}$ and $\mathrm{Mn}$ in groundwater after the release reaches kinetic equilibrium. Lower $\mathrm{pH}$ can make the leaching more thorough, but the neutral environment also increases the amount of Mn. It can be deduced that the pollutants such as organics imported by anthropogenic activities can indeed increase the releases of Fe and $\mathrm{Mn}$ from aquifer sediments into groundwater, thus worsening the issue of groundwater Fe and Mn pollution. The findings provide a deeper insight into the geochemical effects of Fe and $\mathrm{Mn}$ in the natural environment, especially in the groundwater system.
\end{abstract}

Keywords: groundwater pollution; water-sediment interaction; leaching; release; Fe; Mn

\section{Introduction}

Iron and manganese elements are widely distributed in the strata, including aquifer sediments, and they can enter the groundwater through leaching and become the common hydrochemical components [1]. In aquifers around the world, the concentrations of Fe and $\mathrm{Mn}$ in groundwater vary very widely in space, from a few micrograms per liter $[2,3]$ to tens of micrograms per liter or more [4]. Although this difference is related to the spatial distribution of Fe and $\mathrm{Mn}$ in the porous medium of the strata [5,6], it is also greatly related to the high complexities of the geochemistry processes of them $[7,8]$, which are controlled by the hydrogeochemical environment $[9,10]$ and have not yet been well understood [11]. When the concentrations of Fe and $\mathrm{Mn}$ in groundwater reach certain levels, the water intake facilities, such as pumping wells, can be clogged [11,12], thus greatly shortening the service life of the water intake project [13]. In addition, although Fe and Mn are essential elements of human bodies [14], high concentrations will not only affect the sense of groundwater as drinking water (such as color and iron smell), but also can affect human body health if drinking over a long period of time $[15,16]$. Therefore, the groundwater with too high 
concentrations of Fe and Mn needs to be purified and qualified before drinking [17], which will obviously increase the water treatment process and consequently, increase the water supply cost [18]. As a result, it is not only of great scientific value, but also of great practical significance to study the hydrogeochemistry of Fe and Mn.

Numerous investigations have focused on Fe and Mn pollution in groundwater, especially that for drinking, worldwide, such as in China [19], USA [20,21], European countries [3], and India [22]. These studies have revealed the primary geochemical processes involved in the genesis of Fe- and Mn-rich groundwater [23]. The mechanism that causes the release and mobilization of $\mathrm{Fe}$ and $\mathrm{Mn}$ from aquifer sediments into groundwater in the natural environment is primarily the redox dissolution of Fe- and Mn-bearing minerals [8], such as magnetite, hematite, limonite, siderite, pyrite, manganite, braunite, pyrolusite, and psilomelane [24], sometimes with an impact on the desorption from sediment surface via competition with some other cations. Although Fe and $\mathrm{Mn}$ in groundwater are mainly introduced from the natural environment [25], they are also suspected of being influenced by anthropogenic activities [26]. With the socio-economic development, the impact of anthropogenic activities on groundwater has reached an unprecedented level in recent years [27]. The impact not only causes different degrees of pollution to groundwater by direct discharge of pollutants [28], but also changes the environmental conditions of groundwater (e.g., acid-base properties, redox conditions, $\mathrm{pH}$, and microbiome) $[29,30]$, both of which have been considered to have an impact on the natural environmental processes of Fe and Mn [31]. Organic matter is on the list of the anthropogenic pollutants [32]. The superposition of these anthropogenic pollutants and the chemical components in the natural environment make the hydrogeochemical process more complicated [33]. It has been found that the concentrations of Fe and $\mathrm{Mn}$ in groundwater with higher concentrations of organics are usually higher than those in groundwater without pollution of organics or with lower pollution degree [34]. For example, on the regional scale, such as in the important aquifers in USA [35], China [36], and some other counties [37,38], it has been found that the concentrations of Fe and Mn have increased in the past decades, simultaneously with the increased imports of organics (usually characterized by DOC, COD, or BOD), the anoxic and the acid environment. Simultaneously, on the site scale, such as in waste landfills [36] and polluted sites [39,40], it has also been found that the concentrations of $\mathrm{Fe}$ and $\mathrm{Mn}$ in the surrounding groundwater considerably increased after the operation of those sites for a period of time, while the background values of them in the groundwater were not high, and they were not discharged by those sites [41,42]. However, it should be noted that there were various organics, nitrogen species, or acidbase substances in the main pollutants of these sites [43]. Thus, it is an issue worthy of discussion, whether the positive correlation between $\mathrm{Fe}$ and $\mathrm{Mn}$ in groundwater and those pollutants introduced by anthropogenic activities is a coincidence or an inevitability in the physicochemical mechanism.

The essence of the issue is the interaction between groundwater and sediments and the influencing factors of it, which may be physical, chemical, or even biological [44]. The investigation results show that up to now, few controlled experiments have conducted in-depth research on this interaction. The case studies mentioned above were only in the field investigation stage, and the corresponding conclusions were obtained from statistical analysis on this basis, but lacked mechanism exploration. Based on this, we presume that the increase of organics in groundwater can enhance the interaction between groundwater and sediments, thus increase the releases of $\mathrm{Fe}$ and $\mathrm{Mn}$ from sediments, and finally, increase their concentrations in groundwater. In addition, considering that physical and chemical effects are usually affected by aquatic environmental conditions, we also suspect that changes in $\mathrm{pH}$ will also impact the interaction and even the enhancement. To test the above hypotheses, the aims of this study were designed as follows: (1) to determine the presence of enhancing effects of organic pollution in groundwater on release of Fe and $\mathrm{Mn}$ from aquifer sediments; (2) to identify impacts of aquatic environmental conditions, such as $\mathrm{pH}$, on the enhancing effects; (3) to reveal the mechanisms behind these effects and impacts. 
This study will further the understanding of the roles of pollutants mainly introduced by anthropogenic activities, such as organics, on the geochemical processes of Fe and Mn naturally occurring in environment, especially in the groundwater system. In addition, we also sincerely hope that our efforts in this regard will be helpful for more effective control of groundwater pollution.

\section{Materials and Methods}

\subsection{In Situ Sediments Sampling and Characterization}

The in situ aquifer sediments were sampled in Northeast China (Figure 1a), specifically at a point $\left(45^{\circ} 45^{\prime} 52.58^{\prime \prime} \mathrm{N}, 126^{\circ} 30^{\prime} 12.05^{\prime \prime}\right.$ E) located east of the Songnen Plain (Figure 1b), which belongs to the Songhua River Basin. The sampling site is located on the southern alluvial flat of the Songhua River (Figure 1c), which was formed by the river alluvial deposits, specifically, coarse sand and gravel of the Quaternary Holocene, which are relatively loose. There is strong hydraulic connection between the groundwater and river. In the rainy season, the river can recharge the groundwater [45]. On the contrary, groundwater can recharge the river in other periods [18]. Controlled by the river-groundwater interaction, the depth of the groundwater level around the sampling site ranges from 3 to $5 \mathrm{~m}[46,47]$. In many parts of the river basin, especially in the regions close to the river and the tributaries, the concentrations of Fe can reach tens of milligrams per liter, while Mn and COD can reach several milligrams per liter in the groundwater, which has had a significant impact on the production and life of the local residents [48]. More details about the hydrogeological conditions of the sampling site can be referred to in the study of Zhu et al. (2020) [18].

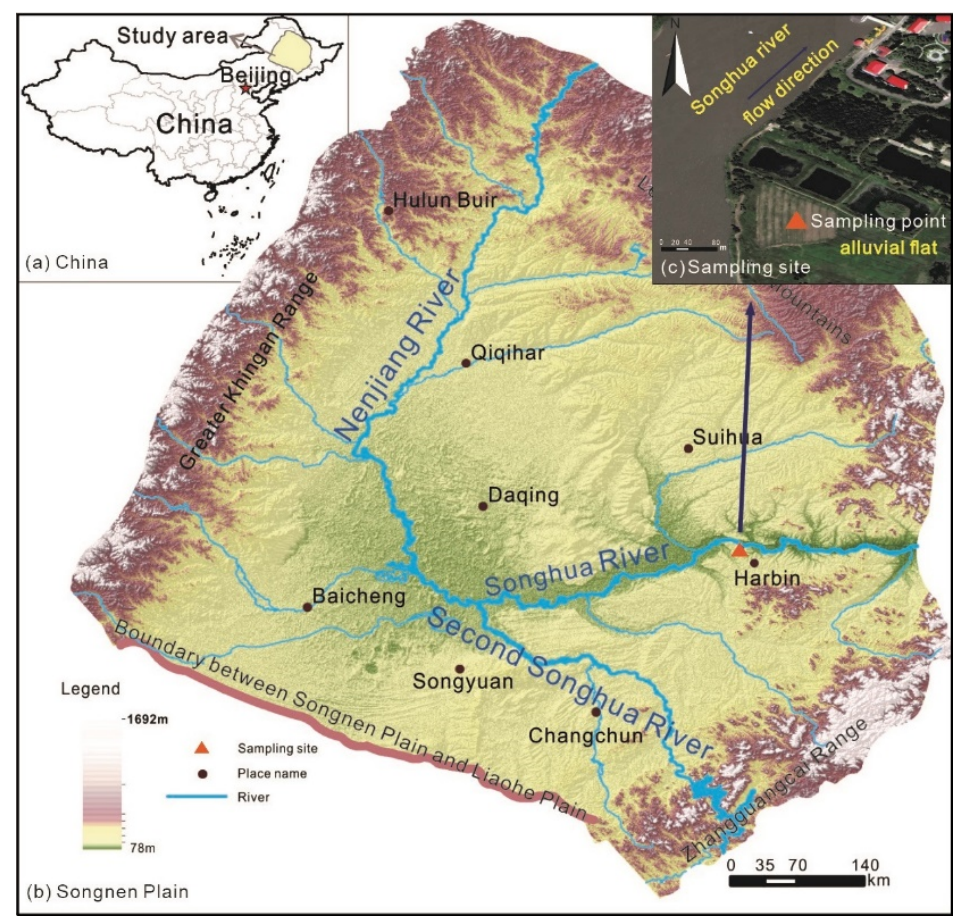

Figure 1. Topographic map of the sampling site, (a) China, (b) Songnen Plain, (c) Sampling site.

The samples of sediments were manually drilled in the phreatic aquifer using a stainless-steel hand drill with long drill pipe. To facilitate comparative analysis, samples were collected from three boreholes, distributed in a straight line perpendicular to the river. The sampling depth was two meters underground, which is in the unsaturated zone, with the thickness of four meters. In order to make the samples less disturbed, the samples were immediately put into impervious and opaque bags after being drilled out, sealed, and subsequently, saved in portable refrigerator. 
All sediment samples were transported to the lab immediately after sampling, followed by determination of the physiochemical properties of them in the lab (Table 1). Before the physicochemical analysis, each sample was thoroughly stirred and mixed to make it as uniform as possible. The particle sizes of the samples were determined by the MS2000 laser particle size analyzer. The lithological characteristics of the sampling points were grayish black, with good sorting and good grinding. $\mathrm{pH}$ was determined by the potentiometric method; $\mathrm{NO}_{3}-\mathrm{N}$ and $\mathrm{NO}_{2}-\mathrm{N}$ were determined by the potassium chloride solution extraction-spectrophotometry; organic matter was determined by potassium dichromate volumetric method by the electric furnace $(1000 \mathrm{w})$ and characterized by TOC; and total Fe and total Mn were determined by the ICP-AES (PerkinElmer Optima 8000, Waltham, MA, USA) method.

Table 1. Physical and chemical properties of the aquifer sediments used for the experiment.

\begin{tabular}{ccccccc}
\hline Sediment & $\mathbf{p H}$ & $\begin{array}{c}\mathrm{NO}_{\mathbf{3}}-\mathbf{N} \\
(\mathbf{m g} / \mathbf{k g})\end{array}$ & $\begin{array}{c}\mathbf{N O}_{\mathbf{2}}-\mathbf{N} \\
(\mathbf{m g} / \mathbf{k g})\end{array}$ & $\begin{array}{c}\mathrm{TOC} \\
(\mathbf{m g} / \mathbf{k g})\end{array}$ & $\begin{array}{c}\text { Total Fe } \\
(\mathbf{m g} / \mathbf{k g})\end{array}$ & $\begin{array}{c}\text { Total Mn } \\
(\mathbf{m g} / \mathbf{k g})\end{array}$ \\
\hline I & 5.87 & 25.5 & 0.105 & 1550 & 18540 & 384 \\
II & 6.24 & 22.6 & 0.134 & 6400 & 22664 & 451 \\
III & 6.11 & 27.5 & 0.12 & 7980 & 27749 & 506 \\
\hline
\end{tabular}

\subsection{Artificial Polluted Groundwater with Organics}

To avoid the interference of other chemical components, the groundwater polluted with organics used for the leaching test was manually made in the lab with ultrapure water and grade pure potassium hydrogen phthalate. Potassium hydrogen phthalate was chosen as the organic substance because it is a standard solution with COD, which makes our experimental results more universal and repeatable. In detail, according to the test needs, potassium hydrogen phthalate solutions of 10, 20, 40, 50, 60, 80, and $100 \mathrm{mg} / \mathrm{L}$ were prepared for use. In addition, the potassium hydrogen phthalate solution of $50 \mathrm{mg} / \mathrm{L}$ was divided into eight parts for use, $\mathrm{pH}$ of which was adjusted to 3, 4, 5, 6, 7, 8, 9, and 10 through adding $\mathrm{HCl}$ or $\mathrm{NaOH}$, according to the needs. Ultrapure water was used for the blank test instead of the polluted groundwater.

\subsection{Chemicals and Utensils}

Other chemicals and reagents used in the test included potassium nitrate, potassium sodium tartrate, Nessler's reagents (sodium hydroxide, mercury iodide, and potassium iodide), 1:1 hydrochloric acid ( $\mathrm{HCl}$ ), sulfamic acid, ascorbic acid, ammonia solution, acetic acid-sodium acetate (Hac-NaAc) buffer solution, hydroxylamine hydrochloride, phenanthroline, and iron standard solution.

Test vessels and equipment used in the test included conical flask $(250 \mathrm{~mL})$, centrifuge tube $(10 \mathrm{~mL}$ and $50 \mathrm{~mL})$, syringe $(10 \mathrm{~mL})$, volumetric flask $(500 \mathrm{~mL}$ and $1000 \mathrm{~mL})$, beaker $(50 \mathrm{~mL})$, graduated cylinder $(50 \mathrm{~mL})$, and $25 \mathrm{~mm}$ diameter hydrophilic filter (water system).

All glassware used were carefully handled before use to ensure the quality of samples. All used glassware was soaked in $10 \%$ nitric acid lotion for $4 \mathrm{~h}$, then rinsed with ultrapure water thrice, and dried for $4 \mathrm{~h}$ at $180{ }^{\circ} \mathrm{C}$. The bottle caps and gaskets were cleaned using an ultrasonic cleaner for $30 \mathrm{~min}$ with $20 \%$ anhydrous ethanol aqueous solution, then rinsed with ultrapure water thrice, and dried naturally.

\subsection{Leaching Test Procedures}

The leaching tests were achieved by the oscillation tests in the conical flasks carried out in the lab (Figure 2). The ultrapure water (or organic solution) and the sediment samples for leaching were added into the conical flasks according to the ratio of liquid to soil of 10:1 in dark condition. Immediately after the addition, the conical flasks were sealed with sealing film and put into a constant temperature oscillator. The conical flasks were transferred to the centrifuge after oscillation, and centrifuged at $5000 \mathrm{r} / \mathrm{min}$ for $15 \mathrm{~min}$. After centrifugation, the supernatant was taken out and filtered with a $0.45 \mu \mathrm{m}$ water 
filter to remove interferences such as suspension, from which the leachate samples were obtained for measurements. To ensure the data quality, parallel samples were made at each sampling point.

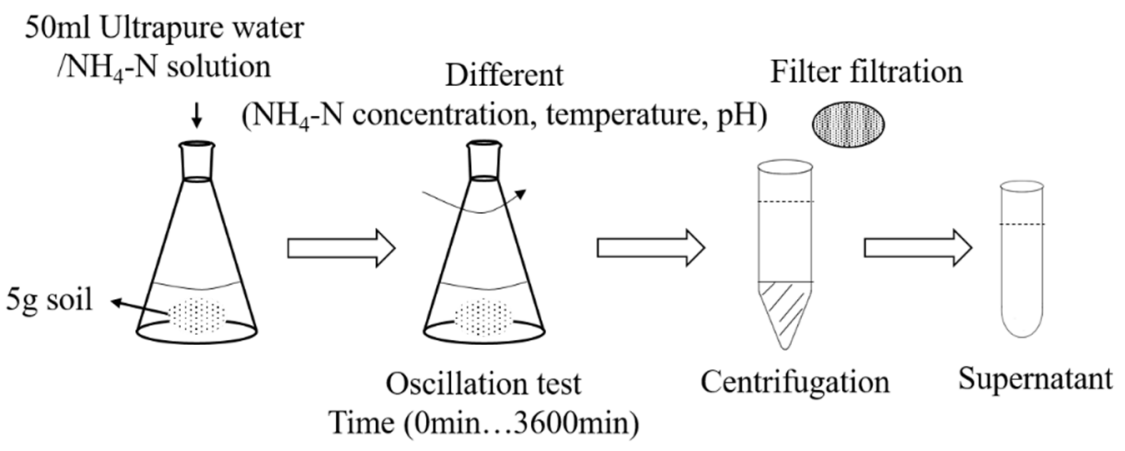

Figure 2. Schematic diagram of the leaching experiment.

To achieve the study aims, four groups of tests (named A, B, C, and D) with different conditions were carried out (Table 2). In each group, three sediment samples were tested independently. In group A, 16 conical flasks were used to test each sediment sample, corresponding to 16 sampling times. Each test of group A lasted $3600 \mathrm{~min}$ to ensure that the leaching processes were fully performed and the physicochemical processes in the sediment-water system reached dynamic equilibrium. The concentration of organics in the ultrapure water used in group A was $50 \mathrm{mg} / \mathrm{L}$, and the test temperature was controlled at $20^{\circ} \mathrm{C}$.

Table 2. Control conditions for the leaching experiments.

\begin{tabular}{|c|c|c|c|c|c|}
\hline Group & Sediment & Sampling Time (min) & Organics $(\mathrm{mg} / \mathrm{L})$ & $\mathrm{pH}$ & Number of Samples \\
\hline A & $\begin{array}{c}\text { I } \\
\text { II } \\
\text { III } \\
\text { I }\end{array}$ & $\begin{array}{c}0,5,10,30,60,90,120,180,360,540 \\
720,1080,1440,1800,2700,3600\end{array}$ & 50 & & 16 \\
\hline B & $\begin{array}{c}\text { II } \\
\text { III } \\
\text { I }\end{array}$ & & $10,20,40,60,80,100$ & & 6 \\
\hline $\mathrm{C}$ & $\begin{array}{c}\text { II } \\
\text { III } \\
\text { I }\end{array}$ & 3600 & 50 & & 3 \\
\hline $\mathrm{D}$ & $\begin{array}{l}\text { II } \\
\text { III }\end{array}$ & & & $3,4,5,6,7,8,9,10$ & 8 \\
\hline
\end{tabular}

A: long-time leaching with continuous monitoring; B: leaching with organics solutions with different concentrations; C: leaching with different $\mathrm{pH}$; sediment: three different sediments (seen in Table 1); sampling time: the time after reaching dynamic equilibrium, except for group A; pH: that of the solution.

In the groups $\mathrm{B}, \mathrm{C}$, and $\mathrm{D}$, the leaching processes were also fully performed, all of which lasted $3600 \mathrm{~min}$, and this duration was based on the results of group A. The concentrations of organics in the ultrapure water used in group B were 10, 20, 40, 60, 80, and $100 \mathrm{mg} / \mathrm{L}$, respectively, and the test temperature was also controlled at $20^{\circ} \mathrm{C}$. The concentration of organics in the ultrapure water used in the group $\mathrm{C}$ was also $50 \mathrm{mg} / \mathrm{L}$, the test temperature was controlled at $20^{\circ} \mathrm{C}$, while $\mathrm{pH}$ of the solution was $3,4,5,6,7,8,9$, and 10 , respectively.

For the purpose of comparative analysis, all the above tests were accompanied by blank tests, that is, the solution for leaching was ultrapure water instead of the polluted groundwater.

\subsection{Leachate Measurements}

The leachate samples were immediately tested for hydrochemistry after preparation. In consideration of the possible physiochemical changes in the leaching processes, the 
following hydrochemical indicators were measured for the collected leachate samples: $\mathrm{Fe}^{2+}$, total Fe, Total $\mathrm{Mn}, \mathrm{NO}_{3}^{-}-\mathrm{N}, \mathrm{Cl}^{-}, \mathrm{pH}, \mathrm{K}, \mathrm{Na}, \mathrm{Ca}, \mathrm{Mg}$, and $\mathrm{SO}_{4}{ }^{2-}$ (Table 3).

Table 3. Items, detection methods, and statistical information of monitoring indicators.

\begin{tabular}{ccc}
\hline Item (Unit) & Detection Method & Level of Detection (Unit) \\
\hline $\mathrm{Fe}(\mathrm{II})$ & O-phenanthroline spectrophotometry & $0.03 \mathrm{mg} / \mathrm{L}$ \\
$\mathrm{TFe}$ & ICP-AES (PerkinElmer Optima 8000) & $0.01 \mathrm{mg} / \mathrm{L}$ \\
$\mathrm{TMn}$ & ICP-AES (PerkinElmer Optima 8000) & $0.001 \mathrm{mg} / \mathrm{L}$ \\
$\mathrm{NO}_{3}^{-}$ & Ion chromatography (Thermo ICS-2100) & $0.02 \mathrm{mg} / \mathrm{L}$ \\
$\mathrm{Cl}$ & Ion chromatography (Thermo ICS-2100) & $0.02 \mathrm{mg} / \mathrm{L}$ \\
$\mathrm{pH}$ & Water quality analyzer (HANNA-HI9828) & $0.007 \mathrm{mg} / \mathrm{L}$ \\
$\mathrm{K}$ & ICP-AES (PerkinElmer Optima 8000) & $0.004 \mathrm{mg} / \mathrm{L}$ \\
$\mathrm{Na}$ & ICP-AES (PerkinElmer Optima 8000) & $0.0002 \mathrm{mg} / \mathrm{L}$ \\
$\mathrm{Ca}$ & ICP-AES (PerkinElmer Optima 8000) & $0.001 \mathrm{mg} / \mathrm{L}$ \\
$\mathrm{Mg}$ & ICP-AES (PerkinElmer Optima 8000) & $0.09 \mathrm{mg} / \mathrm{L}$ \\
\hline
\end{tabular}

COD was determined using potassium dichromate volumetric method. $\mathrm{Fe}^{2+}$ was determined using O-phenanthroline spectrophotometry. Total Fe, total $\mathrm{Mn}, \mathrm{K}, \mathrm{Na}, \mathrm{Ca}$, and $\mathrm{Mg}$ were determined using the ICP-AES (PerkinElmer Optima 8000). $\mathrm{NO}_{3}^{-}-\mathrm{N}, \mathrm{Cl}^{-}$, and $\mathrm{SO}_{4}^{2-}$ were determined using ion chromatography (Thermo ICS-2100, Waltham, MA, USA). $\mathrm{pH}$ was determined using portable multi-parameter rapid water quality analyzer (HANNAHI9828, Beijing, China). An indicative standard sample was tested every 10 samples with an error of less than $10 \%$. All the analytical procedures are in conformance with quality requirements. The error was less than $10 \%$, and the pass rate was $100 \%$.

\section{Results}

\subsection{Changes of $\mathrm{Fe} / \mathrm{Mn}$ with Sediments}

The three samples of the aquifer sediments mainly consisted of fine sand and sand (Figure 3) including quartz, sodium feldspar, and potassium feldspar. The Fe-bearing minerals in the three samples were mainly hematite and bixbyite; and the Mn-bearing minerals were mainly pyrolusite and bixbyite. The three samples were weak acidic with $\mathrm{pH}$ of $5.87-6.24$ (Table 1). $\mathrm{NO}_{3}-\mathrm{N}$ and $\mathrm{NO}_{2}-\mathrm{N}$ of the samples were $22.6-27.5 \mathrm{mg} / \mathrm{kg}$ and $0.105-0.134 \mathrm{mg} / \mathrm{kg}$, and TOC was $1550-7980 \mathrm{mg} / \mathrm{kg}$. Total Fe was $21,360-27,749 \mathrm{mg} / \mathrm{kg}$, and total Mn was $484-506 \mathrm{mg} / \mathrm{kg}$, which is about one fiftieth of that of total Fe. For the convenience of discussion, the three samples are arranged in ascending order according to the Fe contents in the samples, and named I, II, and III (Table 1), respectively. Coincidentally, from sample I to III, the Mn contents are also in ascending order. 

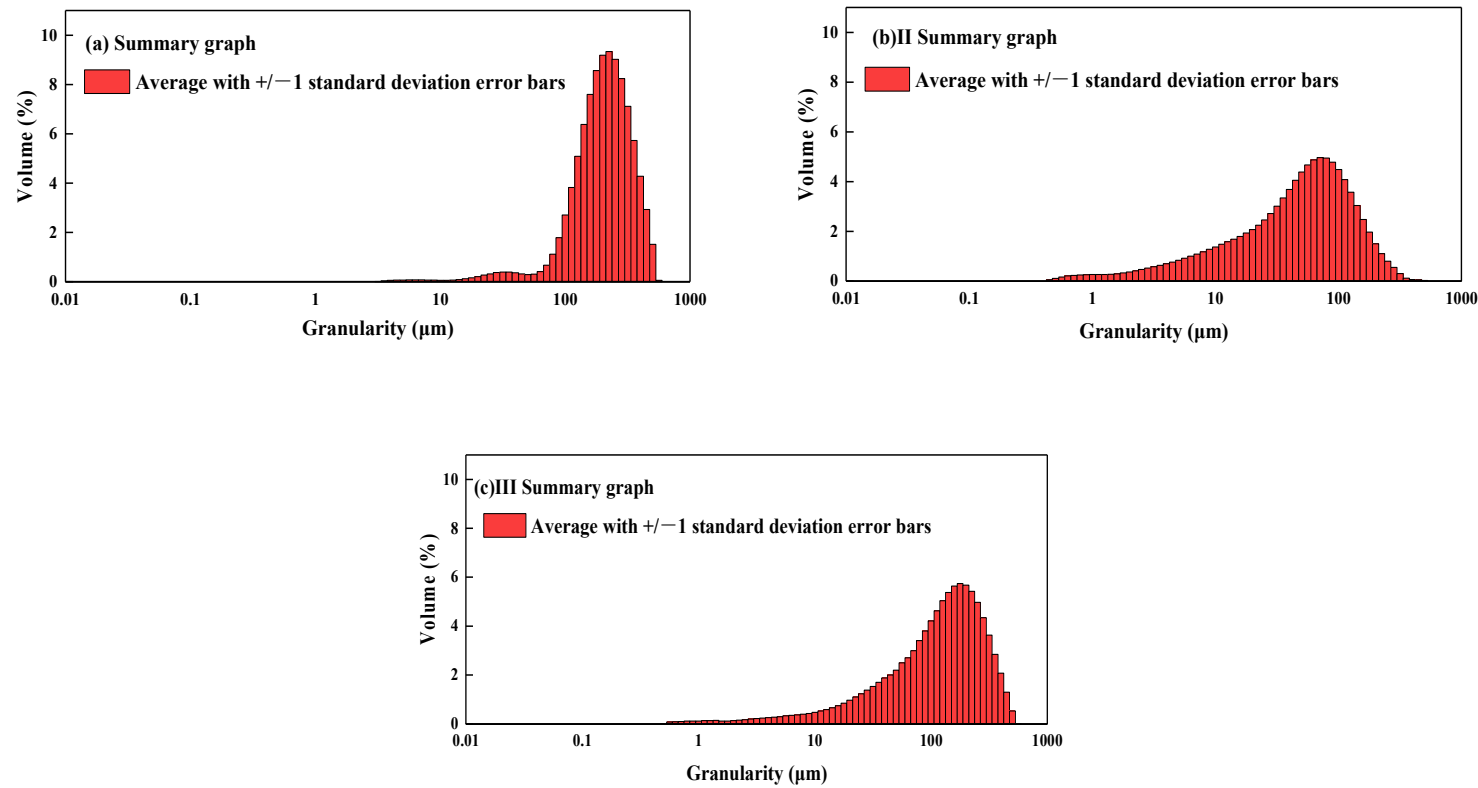

Figure 3. Particle sizes of the collected sediment samples, (a) I sediment, (b) II sediment, (c) III sediment.

After reaching dynamic equilibrium in the organic solution systems of the three sediment samples, the concentrations of Fe of I, II, and III samples were 2.00, 2.44, and $3.89 \mathrm{mg} / \mathrm{L}$, respectively, and the values of Mn were $0.039,0.041$, and $0.051 \mathrm{mg} / \mathrm{L}$, respectively. That is to say, the higher the content in the sediment, the higher the corresponding concentration in the leachate after reaching equilibrium (Figure 4). Specifically, the concentration of $\mathrm{Fe}$ in the leachate increased by $2-37 \%$ for every $1000 \mathrm{mg} / \mathrm{kg}$ increase in the contents of Fe-bearing minerals in the aquifer sediment. Mn's corresponding value was $7-200 \%$ for every $10 \mathrm{mg} / \mathrm{kg}$ increase in the contents of Mn-bearing minerals in the aquifer sediment.
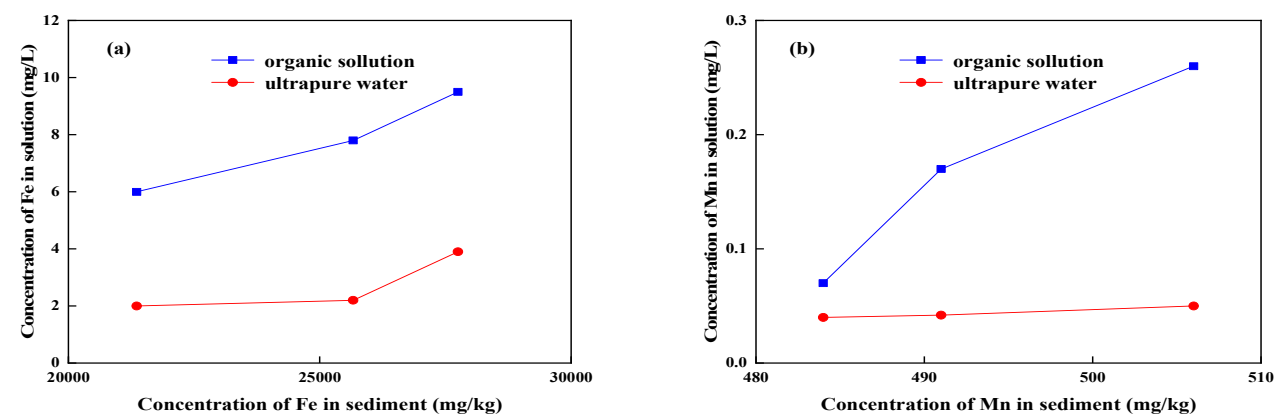

Figure 4. Relationships between equilibrium concentrations of $\mathrm{Fe}$ and $\mathrm{Mn}$ and mineral contents of the sediment samples (temperature $=20^{\circ} \mathrm{C}$ ), (a) Fe, (b) $\mathrm{Mn}$.

\subsection{Changes of $\mathrm{Fe} / \mathrm{Mn}$ with Organics}

The equilibrium concentrations of Fe and $\mathrm{Mn}$ in the leachate increased linearly with the increase of organics concentration of the solution for leaching (Figure 5), that is, the higher the concentration of organics of the solution, the higher the equilibrium concentration of $\mathrm{Fe}$ and $\mathrm{Mn}$ in the leachate. For the three samples, the concentration of $\mathrm{Fe}$ in the leachate increased by $0.3-2.0 \mathrm{mg} / \mathrm{L}$ for every $10 \mathrm{mg} / \mathrm{L}$ increase in the concentration of organics of the solution. The corresponding value of $\mathrm{Mn}$ was $0.003-0.05 \mathrm{mg} / \mathrm{L}$. What is more, compared with the blank tests, Fe and Mn concentration in the experiment tests was significantly higher, for example, even in the test that had only $10 \mathrm{mg} / \mathrm{L}$ organic solution added, the concentration was one and a half times that in blank test. 

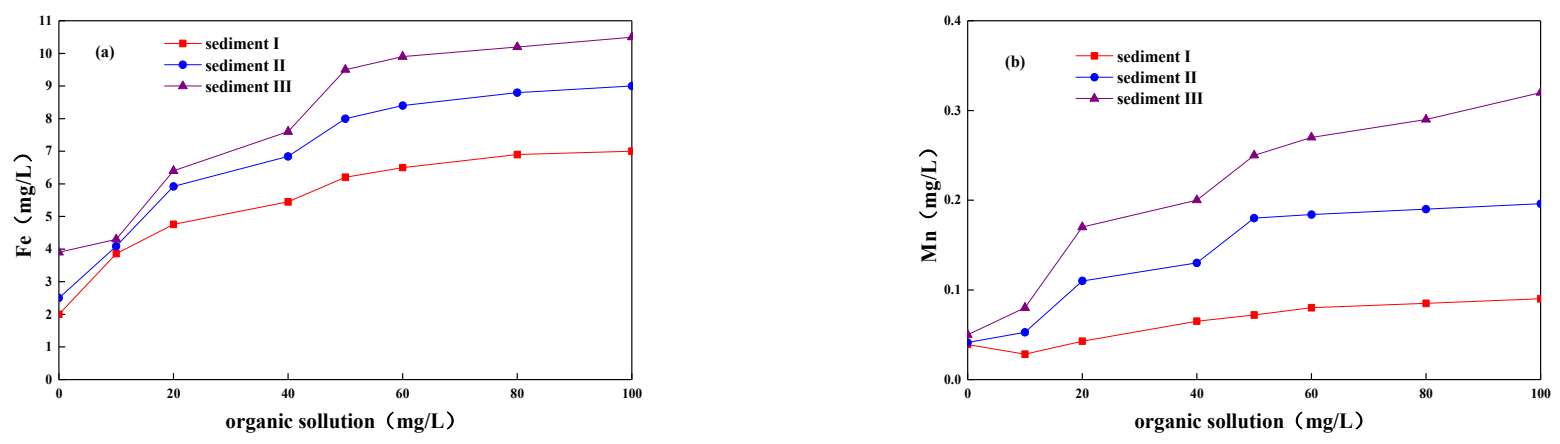

Figure 5. Relationships between equilibrium concentrations of Fe and Mn and organic solution, (a) Fe, (b) Mn.

\subsection{Changes of $\mathrm{Fe} / \mathrm{Mn}$ with Time}

In the early period (within $90 \mathrm{~min}$ from the beginning) of the leaching tests (group A in Table 1), concentrations of Fe and $\mathrm{Mn}$ in the leachate of the three sediment samples increased sharply; in the followed period, generally from 90th minute to 1800th minute, the concentrations still increased on the whole, but the speed slowed down obviously; while from 1800th minute to the end (3600th minute) of the tests, the concentrations were almost unchanged, which could be divided into the final period (the third period; Figure 6). In the whole period, the concentration curves of the three sediment samples showed a similar change trend. The concentration curves of the blank tests also showed a similar trend. The curves of Fe and Mn showed a similar trend. The concentration of Fe of the three sediment samples (I, II, and III), in which $50 \mathrm{mg} / \mathrm{L}$ COD had been added, after reaching dynamic equilibrium was $6.20,8.00$, and $9.50 \mathrm{mg} / \mathrm{L}$, respectively, while the corresponding values of Mn were $0.072,0.18$, and $0.25 \mathrm{mg} / \mathrm{L}$, respectively. As for the blank tests, the corresponding values of Fe were 2.00, 2.50, and $3.90 \mathrm{mg} / \mathrm{L}$, respectively, while the values of Mn were $0.039,0.041$, and $0.051 \mathrm{mg} / \mathrm{L}$, respectively. It is easy to see that the values varied with the sediments, elements, and the degree of organic pollution of water. All in all, the curves of experiment tests and blank tests show the similar change law. The difference between them is the amplitude of Fe and Mn concentration changes. The range of Fe and Mn concentrations in experiment tests is more dramatic, which will be three times that of the blank tests.
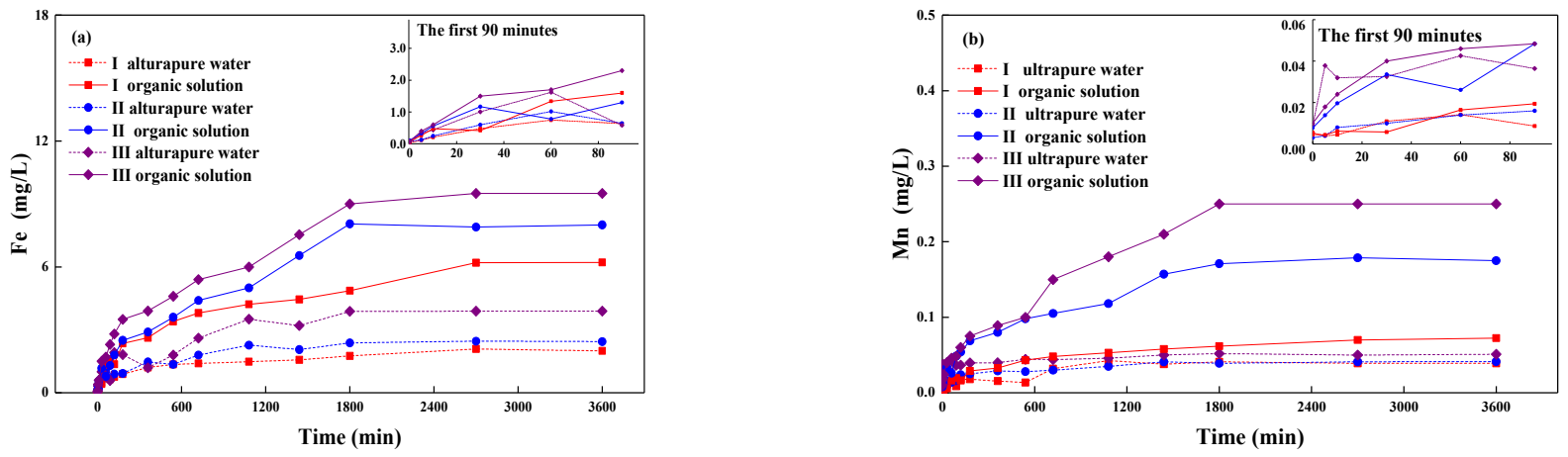

Figure 6. Changes of concentrations of Fe and $\mathrm{Mn}$ in the leachate with time (min), (a) Fe, (b) Mn.

\subsection{Changes of $\mathrm{Fe} / \mathrm{Mn}$ with $\mathrm{pH}$}

The equilibrium concentrations of $\mathrm{Fe}$ and $\mathrm{Mn}$ in the leachate decreased linearly with the increase of $\mathrm{pH}$ (Figure 7), that is, the higher the $\mathrm{pH}$ of the solution for leaching, the lower the equilibrium concentration of $\mathrm{Fe}$ and $\mathrm{Mn}$ in the leachate. For the three samples, the concentration of $\mathrm{Fe}$ in the leachate decreased by $0.2-0.6 \mathrm{mg} / \mathrm{L}$ for every one $\mathrm{pH}$ increase of the solution. The corresponding value of Mn was $0.003-0.02 \mathrm{mg} / \mathrm{L}$. Specifically, the concentration of Fe in the leachate decreased by $10-60 \%$ for every $1 \% \mathrm{pH}$ increase of the 
solution. And the average decrease was $45 \%$. The corresponding value of Mn was $11-80 \%$, and the average decrease was $36 \%$.
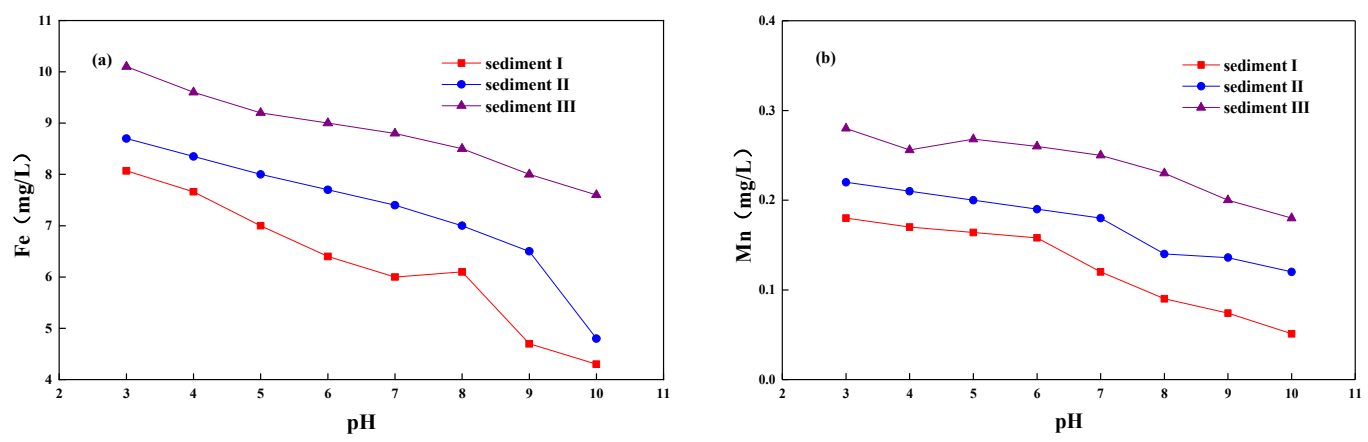

Figure 7. Relationships between equilibrium concentrations of $\mathrm{Fe}$ and $\mathrm{Mn}$ and $\mathrm{pH},(\mathbf{a}) \mathrm{Fe},(\mathbf{b}) \mathrm{Mn}$.

\section{Discussion}

\subsection{Input of Organics Increase Fe/Mn Release}

This set of tests revealed the influences of different physicochemical conditions, such as Fe and Mn contents in the aquifer sediment, organics concentration of the solution for leaching, duration of the leaching, and $\mathrm{pH}$, on the leaching process of $\mathrm{Fe}$ and $\mathrm{Mn}$ from the sediment to the leachate. All these conditions have an impact on the concentrations of $\mathrm{Fe}$ and $\mathrm{Mn}$ in the leachate. In a certain period, the longer the duration, the more fully the leaching, and the higher the concentrations of Fe and $\mathrm{Mn}$ in the leachate, until they reach a dynamic equilibrium between the leachate and the sediment. The previous study indicated that the average concentration of $\mathrm{Fe}$ and $\mathrm{Mn}$ in the studied area under natural conditions is $3.5 \mathrm{mg} / \mathrm{L}$ and $0.06 \mathrm{mg} / \mathrm{L}$, respectively [18]. The average concentration comparing with our study is a little higher. The concentration of Fe and Mn in whole Songnen Plain is relatively high, and the alluvial flat is particularly high in the region. The alluvial flat is a hyporheic zone with a strong exchange, accumulation of organic matter, and human influence, which may be why Fe and Mn content in the alluvial flat is particularly high in the region [25]. The increases of Fe and Mn contents in the sediment and the organics concentration in the solution for leaching is favorable to the increases of Fe and Mn concentrations in the leachate. When the Fe and Mn contents in the sediment were 21,360-27,749 mg/kg and $484-506 \mathrm{mg} / \mathrm{kg}$, respectively, and the reaction temperature was set at $20^{\circ} \mathrm{C}$, the equilibrium concentrations of Fe and $\mathrm{Mn}$ increased by $0.3-2.0 \mathrm{mg} / \mathrm{L}$ and $0.003-0.05 \mathrm{mg} / \mathrm{L}$, respectively, for each $10 \mathrm{mg} / \mathrm{L}$ increase of organics concentration of the solution for leaching.

In the existing environmental hydrogeological investigations, organic pollution of groundwater has been found to enhance the release of Fe and $\mathrm{Mn}$ from aquifer sediments into groundwater [49], especially in those aquifers with abundant Fe and Mn contents. This enhancement, induced by the groundwater pollution with organics, increases the concentrations of $\mathrm{Fe}$ and $\mathrm{Mn}$ in groundwater to different degrees, and even makes groundwater in some regions unpotable considering Fe and Mn. For example, McMahon et al. (2019) [2] revealed that the concentration of Mn was related to DOC from the soils in USA. Broclawik et al. (2020) [50] found that the presence of methane contributes to the depletion of the sediment in ferric iron compounds, on the other words, increasing the iron ions in the solution.

\subsection{Cause of Enhanced Releases of Fe and Mn}

It can be seen from the results that the leaching of solution with $\mathrm{pH}$ of 7 can also release Fe and $\mathrm{Mn}$ from sediment to water, which can be mainly attributed to the leaching and dissolution function of the water [50]. The common physicochemical conditions for groundwater leaching and chemical reactions are as follows. First, the existence of soluble components is the decisive factor. There are easily soluble Fe and Mn components in the sediment, and the higher the content of the component, the more conducive it is to leaching. 
Second, data from this study demonstrate that acidic conditions are more conducive to the leaching. The lower $\mathrm{pH}$ gives rise to more complete leaching, for example, the acid pickling and rust removing. Third, time is an essential factor during the leaching and chemical reactions. The sufficiency of leaching and reaction is directly proportional to the time. Therefore, we could conclude that leaching occurs with minerals. This explains why Fe and $\mathrm{Mn}$ are detected in some natural groundwater without impacts of anthropogenic activities [51].

Previous studies have shown that organic matter can redox [52] and complex with metal minerals [34] or co-precipitate with metal elements [44]. Specifically, it reduces the redox potential in groundwater, which creates an environment more suitable for the presence of reductive substances [53,54]. In other words, the high-valent oxidation of $\mathrm{Fe}$ and $\mathrm{Mn}$ in the sediments transfers to the lower reduced state by the effects of organics matter. As for our study, small amounts of $\mathrm{K}, \mathrm{Ca}, \mathrm{Na}$, and $\mathrm{Mg}$ were also detected in the leachate along with the release of $\mathrm{Fe}$ and $\mathrm{Mn}$ from the sediment (Figure 8), which indicated that there were water-sediment interactions occurring. In addition, the reason of the unusually high concentration of $\mathrm{K}$ was the adding of the potassium hydrogen phthalate. The redox was supposed the major reaction occurring [55]. Potassium hydrogen phthalate is the reducing agent, providing electrons to promote the reduction and dissolution of minerals [34]. Noteworthy, the complex associates with Fe to improve the stable upper limit of Fe(III) [56], which leads to higher concentration of Fe(III) in the solution [57,58]. In addition, organic-associated Fe and Mn are more stable than dissolved Fe and Mn ions [44], which can also be beneficial to the metal oxides dissolution (Figure 9). Therefore, potassium hydrogen phthalate will promote the Fe and Mn release.
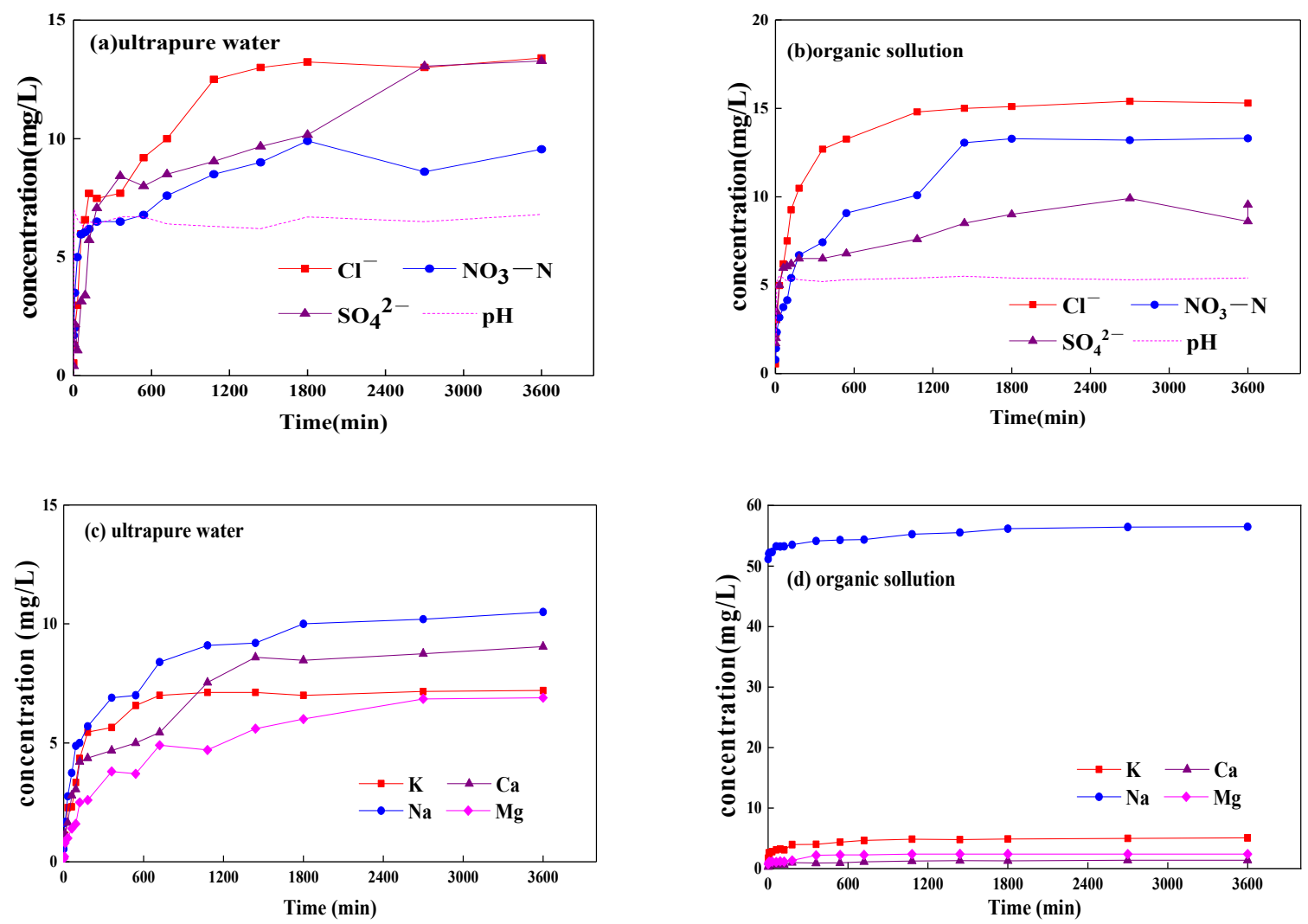

Figure 8. Changes of other concerned indicators $(\mathrm{K}, \mathrm{Na}, \mathrm{Ca}, \mathrm{Mg}$, and $\mathrm{pH})$ in the leachate with time (take I as an example, the other rules are roughly the same as I), (a,c) ultrapure water, $(\mathbf{b}, \mathbf{d})$ organic solution. 


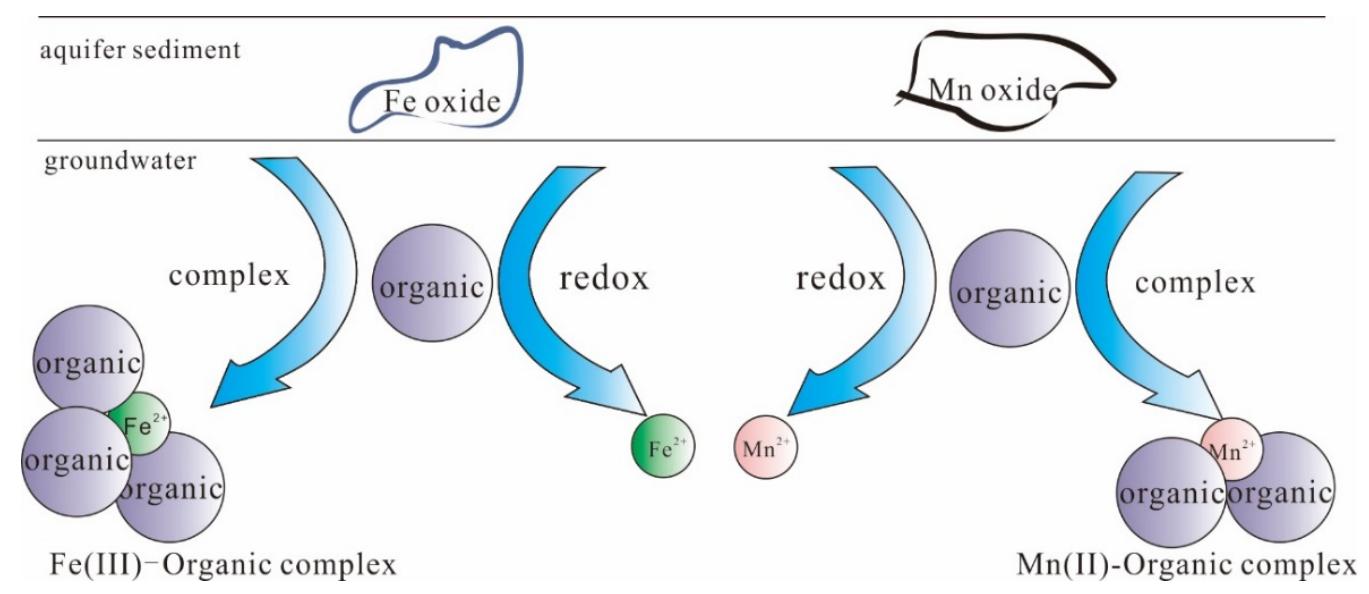

Figure 9. Mechanism of the increased releases of Fe and Mn from sediments to groundwater induced by inputs of organics.

Results signify that $\mathrm{pH}$ influences the release of $\mathrm{Fe}$ and $\mathrm{Mn}$. Lower $\mathrm{pH}$ results in further adsorption, causing more complexation and more release, which is consistent with our experimental results. Specifically, when the $\mathrm{pH}$ is below the PZC (the point of zero charge), there are electrostatic interactions between the positively charged metal oxides and negatively charged phthalic, which leads to adsorption. On the contrary, when the $\mathrm{pH}$ is above the PZC [59], they will repel each other, causing desorption. Noteworthy, adsorption can accelerate the complexation reaction, and the product desorbs little as the $\mathrm{pH}$ increases.

After analyzing the data, we find that there is liner relationship between the $\mathrm{pH}$ and the concentrations of $\mathrm{Fe}$ and $\mathrm{Mn}$. The formulas show that the $\mathrm{pH}$ has more significant impact.

$$
\begin{aligned}
& C_{\mathrm{Fe}}=-0.442 \mathrm{pH}+10.366\left(\mathrm{R}^{2}=0.9635\right) \\
& \mathrm{C}_{\mathrm{Mn}}=-0.0090 \mathrm{pH}+0.2236\left(\mathrm{R}^{2}=0.983\right)
\end{aligned}
$$

\subsection{Implications for Pollution Control}

With the rapid social and economic development, anthropogenic activities make the total amount of activated organics on the earth increase dramatically [60,61]. The artificial input of organic pollutants will not only lead to organic pollution of groundwater, but will also potentially worsen other water quality indicators and the surrounding environment of groundwater by changing the natural cycle of geochemical elements [62] and temperature, such as demonstrated with $\mathrm{Fe}$ and $\mathrm{Mn}$ in our study. Therefore, the implications of controlling organic pollution are not limited to organic pollution itself. Some other elements including Fe and Mn would be affected by the organic pollution and then influence the environment [63].

To monitoring organic pollution, improving the methods for assessing groundwater organic contamination is necessary. There are some methods that have been proposed recently $[64,65]$. Based on our study, we suggest more relevant indicators should be brought into the test list, such as Fe and Mn, and some recent field studies have taken them into the indicators [66]. In recent years, the number of studies on regional Fe and Mn investigation have increased worldwide [2]. It will be the guidance for the groundwater remediation and also should be put in the pollutant inventory. In addition, there has been a considerable amount of research into the effects of biogeochemical processes on organics [67-69]. The relationship between organic pollution and microbial communities in groundwater also will be a focus for future research, which will, in addition, have positive effects on finding the source of pollution.

Although we innovate techniques constantly, the remediation process itself still has a negative impact on the groundwater environment. Minimizing this negative impact will be a focus in the future, so remediating groundwater by controlling the biogeochemical reactions between minerals, microbes, and different elements in groundwater becomes 
more and more valued [70]. All in all, because of the active chemical reactions in the environment, using the interaction between organic pollution microbial and primary chemical components of the environment, such as Fe and Mn, to conduct environmental remediation may be a worthy direction for future environmental remediation, which has actually caught the attention of scientists in recent years [31,59]. Our study can be a reference for related research. The factors affecting Fe and Mn and organics have been studied in our research, which may become the basis of future feasible solutions.

\section{Conclusions}

This study reveals that Fe and Mn can release from Fe- and Mn-bearing minerals of aquifer sediments through groundwater leaching. It also further proves the hypothesis that the input of pollutant such as organics into groundwater through anthropogenic activities indeed can considerably enhance the leaching, which can cause the concentrations of Fe and $\mathrm{Mn}$ to increase exponentially, far more than those only obtained from natural groundwatersediments interactions. The higher the contents of Fe- and Mn-bearing minerals in aquifer sediments, the higher the concentrations of $\mathrm{Fe}$ and $\mathrm{Mn}$ in groundwater after reaching dynamic equilibrium between the sediment and the groundwater. Acidification of the groundwater environment can make the leaching more thorough.

The study explains well why the groundwater concentrations of Fe and Mn present great spatial differences in the natural environment worldwide. It is also deduced that the abnormal increase of groundwater concentrations of Fe and $\mathrm{Mn}$ in some aquifers can be mainly attributed to the anthropogenic activities, especially those related to organics emissions. In addition, the acidification of the water environment, which is mainly caused by anthropogenic activities, should be also responsible for the abnormal increase. Thus, groundwater pollution control may be not only effective to those pollutants discharged directly by anthropogenic activities, but may also be related to those species existing in the natural environment. Increased attention should be paid to the significance of organics on the geochemical processes of Fe and $\mathrm{Mn}$ in the natural environment, especially in the groundwater-sediment system, which will also be favorable for the further development of groundwater pollution control measures.

Author Contributions: Methodology, Y.Z. and X.X.; formal analysis, X.L. and Y.H.; investigation, X.X.; data curation, X.L. and H.L.; writing-original draft, X.L.; writing-review and editing, Y.Z.; supervision, J.W.; funding acquisition, Y.T. and Y.Z. All authors have read and agreed to the published version of the manuscript.

Funding: This work was supported by the Major Science and Technology Program for Water Pollution Control and Treatment (No. 2018ZX07101005-04), the National Natural Science Foundation of China (No. 42077170 and 41831283), Beijing Advanced Innovation Program for Land Surface Science of China, and the 111 Project of China [B16020].

Data Availability Statement: Not applicable.

Conflicts of Interest: The authors declare no conflict of interest.

\section{References}

1. Wu, B.; Amelung, W.; Xing, Y.; Bol, R.; Berns, A.E. Iron cycling and isotope fractionation in terrestrial ecosystems. Earth Sci. Rev. 2019, 190, 323-352. [CrossRef]

2. McMahon, P.B.; Belitz, K.; Reddy, J.E.; Johnson, T.D. Elevated Manganese Concentrations in United States Groundwater, Role of Land Surface-Soil-Aquifer Connections. Environ. Sci. Technol. 2019, 53, 29-38. [CrossRef]

3. Dippong, T.; Mihali, C.; Hoaghia, M.A.; Cical, E.; Cosma, A. Chemical modeling of groundwater quality in the aquifer of Seini town-Somes Plain, Northwestern Romania. Ecotoxicol. Environ. Saf. 2019, 168, 88-101. [CrossRef] [PubMed]

4. VanTruc, N.; ThiDieuHien, V.; ThanhDai, T.; ThiNhuKhanh, N.; ThanhBinh, N.; BaoTrong, D.; XuanThanh, B. Arseniccontaminated groundwater and its potential health risk: A case study in Long An and Tien Giang provinces of the Mekong Delta, Vietnam. Environ. Sci. Pollut. Res. 2020. [CrossRef]

5. Li, X.; Zhang, W.; Qin, Y.; Ma, T.; Zhou, J.; Du, S. Fe-colloid cotransport through saturated porous media under different hydrochemical and hydrodynamic conditons Water Res. Water Res. 2019, 647, 494-506. [CrossRef] 
6. Socié, A.; Dubois, F.; Monerie, Y.; Perales, F. Multibody approach for reactive transport modeling in discontinuous-heterogeneous porous media. Computat. Geosci. 2021. [CrossRef]

7. Ying, S.C.; Schaefer, M.V.; Cock-Esteb, A.; Li, J.; Fendorf, S. Depth Stratification Leads to Distinct Zones of Manganese and Arsenic Contaminated Groundwater. Environ. Sci. Technol. 2017, 51, 8926-8932. [CrossRef] [PubMed]

8. Moon, J.W.; Paradis, C.J.; Joyner, D.C.; von Netzer, F.; Majumder, E.L.; Dixon, E.R.; Podar, M.; Ge, X.; Walian, P.J.; Smith, H.J.; et al. Characterization of subsurface media from locations up- and down-gradient of a uranium-contaminated aquifer. Chemosphere 2020, 255, 126951. [CrossRef] [PubMed]

9. Reyes-Toscano, C.A.; Alfaro-Cuevas-Villanueva, R.; Cortés-Martínez, R.; Morton-Bermea, O.; Hernández-Álvarez, E.; BuenrostroDelgado, O.; Ávila-Olivera, J.A. Hydrogeochemical Characteristics and Assessment of Drinking Water Quality in the Urban Area of Zamora, Mexico. Water 2020, 12, 556. [CrossRef]

10. Shrestha, S.; Sattar, H.; Khattak, M.S.; Wang, G.; Babur, M. Evaluation of adaptation options for reducing soil erosion due to climate change in the Swat River Basin of Pakistan. Ecol. Eng. 2020, 158, 106017. [CrossRef]

11. Jia, Y.; Xi, B.; Jiang, Y.; Guo, H.; Yang, Y.; Lian, X.; Han, S. Distribution, formation and human-induced evolution of geogenic contaminated groundwater in China: A review. Sci. Total. Environ. 2018, 643, 967-993. [CrossRef] [PubMed]

12. Liu, G.; Zhang, Y.; Knibbe, W.-J.; Feng, C.; Liu, W.; Medema, G.; van der Meer, W. Potential impacts of changing supply-water quality on drinking water distribution: A review. Water Res. 2017, 116, 135-148. [CrossRef] [PubMed]

13. Li, G.; Ma, X.; Chen, R.; Yu, Y.; Tao, H.; Shi, B. Field studies of manganese deposition and release in drinking water distribution systems: Insight into deposit control. Water Res. 2019, 163, 114897. [CrossRef] [PubMed]

14. Liu, Y.; Ma, T.; Chen, J.; Xiao, C.; Liu, R.; Du, Y.; Fendorf, S. Contribution of clay-aquitard to aquifer iron concentrations and water quality. Sci. Total. Environ. 2020, 741, 140061. [CrossRef]

15. Zhai, Y.; Lei, Y.; Wu, J.; Teng, Y.; Wang, J.; Zhao, X.; Pan, X. Does the groundwater nitrate pollution in China pose a risk to human health? A critical review of published data. Environ. Sci. Pollut. $R$ 2016, 24, 3640-3653. [CrossRef]

16. Wu, J.; Li, J.; Teng, Y.; Chen, H.; Wang, Y. A partition computing-based positive matrix factorization (PC-PMF) approach for the source apportionment of agricultural soil heavy metal contents and associated health risks. J. Hazard. Mater. 2020, $388,121766$. [CrossRef]

17. Zhai, Y.; Zhao, X.; Teng, Y.; Li, X.; Zhang, J.; Wu, J.; Zuo, R. Groundwater nitrate pollution and human health risk assessment by using HHRA model in an agricultural area, NE China. Ecotoxicol. Environ. Saf. 2017, 137, 130-142. [CrossRef] [PubMed]

18. Zhu, Y.; Zhai, Y.; Teng, Y.; Wang, G.; Du, Q.; Wang, J.; Yang, G. Water supply safety of riverbank filtration wells under the impact of surface water-groundwater interaction: Evidence from long-term field pumping tests. Sci. Total. Environ. 2020, 711, 135141. [CrossRef]

19. Chen, L.; Ma, T.; Wang, Y.; Zheng, J. Health risks associated with multiple metal(loid)s in groundwater: A case study at Hetao Plain, northern China. Environ. Pollut. 2020, 263, 114562. [CrossRef]

20. Johnson, C.D.; Nandi, A.; Joyner, T.A.; Luffman, I. Iron and Manganese in Groundwater: Using Kriging and GIS to Locate High Concentrations in Buncombe County, North Carolina. Ground Water 2018, 56, 87-95. [CrossRef]

21. Dean, W.E.; Neff, B.P.; Rosenberry, D.O.; Winter, T.C.; Parkhurst, R. The Significance of Ground Water to the Accumulation of Iron and Manganese in the Sediments of Two Hydrologically Distinct Lakes in North-Central Minnesota: A Geological Perspective. Ground Water 2003, 41, 951-963. [CrossRef]

22. Vega, M.A.; Kulkarni, H.V.; Johannesson, K.H.; Taylor, R.J.; Datta, S. Mobilization of co-occurring trace elements (CTEs) in arsenic contaminated aquifers in the Bengal basin. Appl. Geochem. 2020, 122, 104709. [CrossRef]

23. Degnan, J.R.; Lindsey, B.D.; Levitt, J.P.; Szabo, Z. The relation of geogenic contaminants to groundwater age, aquifer hydrologic position, water type, and redox conditions in Atlantic and Gulf Coastal Plain aquifers, eastern and south-central USA. Sci. Total. Environ. 2020, 723, 137835. [CrossRef]

24. Bloise, A.; Miriello, D.; de Rosa, R.; Vespasiano, G.; Fuoco, I.; de Luca, R.; Barrese, E.; Apollaro, C. Mineralogical and Geochemical Characterization of Asbestiform Todorokite, Birnessite, and Ranciéite, and Their host Mn-Rich Deposits from Serra D'Aiello (Southern Italy). Fibers 2020, 8, 9. [CrossRef]

25. Zhai, Y.; Zheng, F.; Zhao, X.; Xia, X.; Teng, Y. Identification of hydrochemical genesis and screening of typical groundwater pollutants impacting human health: A case study in Northeast China. Environ. Pollut. 2019, 252, 1202-1215. [CrossRef] [PubMed]

26. Li, Q.; Zhang, H.; Guo, S.; Fu, K.; Liao, L.; Xu, Y.; Cheng, S. Groundwater pollution source apportionment using principal component analysis in a multiple land-use area in southwestern China. Environ. Sci. Pollut. Res. Int. 2020, 27, 9000-9011. [CrossRef]

27. Zhang, X.; He, J.; He, B.; Sun, J. Assessment, formation mechanism, and different source contributions of dissolved salt pollution in the shallow groundwater of Hutuo River alluvial-pluvial fan in the North China Plain. Environ. Sci. Pollut. Res. Int. 2019, 26, 35742-35756. [CrossRef]

28. Cao, X.; Lu, Y.; Wang, C.; Zhang, M.; Yuan, J.; Zhang, A.; Song, S.; Baninla, Y.; Khan, K.; Wang, Y. Hydrogeochemistry and quality of surface water and groundwater in the drinking water source area of an urbanizing region. Ecotoxicol. Environ. Saf. 2019, 186, 109628. [CrossRef]

29. Li, Q.; Wang, G.; Wang, H.; Shrestha, S.; Xue, B.; Sun, W.; Yu, J. Macrozoobenthos variations in shallow connected lakes under the influence of intense hydrologic pulse changes. J. Hydrol. 2020, 584, 124755. [CrossRef] 
30. Yang, Y.; Hu, M.; Zhou, D.; Fan, W.; Wang, X.; Huo, M. Bioremoval of $\mathrm{Cu}^{2+}$ from CMP wastewater by a novel copper-resistant bacterium Cupriavidus gilardii CR3: Characteristics and mechanisms. RSC Adv. 2017, 7, 18793-18802. [CrossRef]

31. Latif, A.; Sheng, D.; Sun, K.; Si, Y.; Azeem, M.; Abbas, A.; Bilal, M. Remediation of heavy metals polluted environment using Fe-based nanoparticles: Mechanisms, influencing factors, and environmental implications. Environ. Pollut. 2020, $264,114728$. [CrossRef]

32. Ma, D.; Wu, J.; Yang, P.; Zhu, M. Coupled Manganese Redox Cycling and Organic Carbon Degradation on Mineral Surfaces. Environ. Sci. Technol. 2020. [CrossRef]

33. Wallis, I.; Prommer, H.; Berg, M.; Siade, A.J.; Sun, J.; Kipfer, R. The river-groundwater interface as a hotspot for arsenic release. Nat. Geosci. 2020, 13, 288-295. [CrossRef]

34. Liu, W.; Wang, Y.; Li, J.; Qian, K.; Xie, X. Indices of the dual roles of OM as electron donor and complexing compound involved in As and Fe mobilization in aquifer systems of the Datong Basin. Environ. Pollut. 2020, 262, 114305. [CrossRef]

35. Bryant, S.R.; Sawyer, A.H.; Briggs, M.A.; Saup, C.M.; Nelson, A.R.; Wilkins, M.J.; Christensen, J.N.; Williams, K.H. Seasonal manganese transport in the hyporheic zone of a snowmelt-dominated river (East River, Colorado, USA). Hydrogeol. J. 2020, 28, 1323-1341. [CrossRef]

36. Ma, Y.; Wang, Z.; Ma, T.; Chen, S. Spatial distribution characteristics and influencing factors of organic carbon in sediments of Tongshun River riparian zone. Chemosphere 2020, 252, 126322. [CrossRef]

37. Papp, D.C.; Cociuba, I.; Baciu, C.; Cozma, A. Origin and Geochemistry of Mine Water and its Impact on the Groundwater and Surface Running Water in Post-mining Environments: Zlatna Gold Mining Area (Romania). Aquat. Geochem. 2017, 23, 247-270. [CrossRef]

38. Thayalakumaran, T.; Lenahan, M.J.; Bristow, K.L. Dissolved Organic Carbon in Groundwater Overlain by Irrigated Sugarcane. Ground Water 2015, 53, 525-530. [CrossRef]

39. Zhu, G.; Wu, X.; Ge, J.; Liu, F.; Zhao, W.; Wu, C. Influence of mining activities on groundwater hydrochemistry and heavy metal migration using a self-organizing map (SOM). J. Clean. Prod. 2020, 257, 120664. [CrossRef]

40. Zhai, Y.; Ma, T.; Zhou, J.; Li, X.; Liu, D.; Wang, Z.; Qin, Y.; Du, Q. Impacts of leachate of landfill on the groundwater hydrochemistry and size distributions and heavy metal components of colloids: A case study in NE China. Environ. Sci. Pollut. R 2019, 26, 5713-5723. [CrossRef]

41. Du, Y.; Deng, Y.; Ma, T.; Xu, Y.; Tao, Y.; Huang, Y.; Liu, R.; Wang, Y. Enrichment of Geogenic Ammonium in Quaternary Alluvial-Lacustrine Aquifer Systems: Evidence from Carbon Isotopes and DOM Characteristics. Environ. Sci. Technol. 2020, 54, 6104-6114. [CrossRef] [PubMed]

42. Barhoumi, B.; Beldean-Galea, M.S.; Al-Rawabdeh, A.M.; Roba, C.; Martonos, I.M.; Balc, R.; Kahlaoui, M.; Touil, S.; Tedetti, M.; Driss, M.R.; et al. Occurrence, distribution and ecological risk of trace metals and organic pollutants in surface sediments from a Southeastern European river (Somesu Mic River, Romania). Sci. Total. Environ. 2019, 660, 660-676. [CrossRef] [PubMed]

43. Nguyen, B.T.; Nguyen, T.M.T.; Bach, Q.-V. Assessment of groundwater quality based on principal component analysis and pollution source-based examination: A case study in Ho Chi Minh City, Vietnam. Environ. Monit. Assess 2020, 192, 395. [CrossRef] [PubMed]

44. Chen, C.; Hall, S.J.; Coward, E.; Thompson, A. Iron-mediated organic matter decomposition in humid soils can counteract protection. Nat. Commun. 2020, 11, 2255. [CrossRef] [PubMed]

45. Yinglan, A.; Wang, G.; Liu, T.; Xue, B.; Kuczera, G. Spatial variation of correlations between vertical soil water and evapotranspiration and their controlling factors in a semi-arid region. J. Hydrol. 2019, 574, 53-63. [CrossRef]

46. Zhu, Y.; Zhai, Y.; Du, Q.; Teng, Y.; Wang, J.; Yang, G. The impact of well drawdowns on the mixing process of river water and groundwater and water quality in a riverside well field, Northeast China. Hydrol. Process. 2019, 33, 945-961. [CrossRef]

47. Gong, H.; Pan, Y.; Zheng, L.; Li, X.; Zhu, L.; Zhang, C.; Huang, Z.; Li, Z.; Wang, H.; Zhou, C. Long-term groundwater storage changes and land subsidence development in the North China Plain (1971-2015). Hydrogeol. J. 2018, 26, 1417-1427. [CrossRef]

48. Zhai, Y.; Xia, X.; Yang, G.; Lu, H.; Ma, G.; Wang, G.; Teng, Y.; Yuan, W.; Shrestha, S. Trend, seasonality and relationships of aquatic environmental quality indicators and implications: An experience from Songhua River, NE China. Ecol. Eng. 2020, 145, 105706. [CrossRef]

49. Liu, S.; Liu, H.; Wang, Z.; Cui, Y.; Chen, R.; Peng, Z.; Yuan, S.; Shi, L. Benzene promotes microbial Fe(III) reduction and flavins secretion. Geochim. Cosmochim. Acta 2019, 264, 92-104. [CrossRef]

50. Huang, P.; Han, S. Study of multi-aquifer groundwater interaction in a coal mining area in China using stable isotopes and major-ion chemical data. Environ. Earth Sci. 2016, 76, 1-10. [CrossRef]

51. Wang, A.; Hu, X.; Wan, Y.; Mahai, G.; Jiang, Y.; Huo, W.; Zhao, X.; Liang, G.; He, Z.; Xia, W.; et al. A nationwide study of the occurrence and distribution of atrazine and its degradates in tap water and groundwater in China: Assessment of human exposure potential. Chemosphere 2020, 252, 126533. [CrossRef]

52. McMahon, P.B.; Chapelle, F.H. Redox processes and water quality of selected principal aquifer systems. Ground Water 2008, 46 , 259-271. [CrossRef] [PubMed]

53. Kim, D. Influence of Iron Speciation on Redox Cycling and Reactivity with Persistent Organic Contaminants. Ph.D. Thesis, University of Illinois at Urbana-Champaign, Champaign, IL, USA, 2009.

54. Amarathunga, U.; Diyabalanage, S.; Bandara, U.G.C.; Chandrajith, R. Environmental factors controlling arsenic mobilization from sandy shallow coastal aquifer sediments in the Mannar Island, Sri Lanka. Appl. Geochem. 2019, 100, 152-159. [CrossRef] 
55. Su, X.; Lu, S.; Yuan, W.; Woo, N.C.; Dai, Z.; Dong, W.; Du, S.; Zhang, X. Redox zonation for different groundwater flow paths during bank filtration: A case study at Liao River, Shenyang, northeastern China. Hydrogeol. J. 2018, 26, 1573-1589. [CrossRef]

56. Sader, J.A.; Hattori, K.; Hamilton, S.; Brauneder, K. Metal binding to dissolved organic matter and adsorption to ferrihydrite in shallow peat groundwaters: Application to diamond exploration in the James Bay Lowlands, Canada. Appl. Geochem. 2011, 26, 1649-1664. [CrossRef]

57. Lan, S.; Wang, X.; Xiang, Q.; Yin, H.; Tan, W.; Qiu, G.; Liu, F.; Zhang, J.; Feng, X. Mechanisms of Mn(II) catalytic oxidation on ferrihydrite surfaces and the formation of manganese (oxyhydr)oxides. Geochim. Cosmochim. Acta 2017, 211, 79-96. [CrossRef]

58. Li, X.; Guo, H.; Zheng, H.; Xiu, W.; He, W.; Ding, Q. Roles of different molecular weights of dissolved organic matter in arsenic enrichment in groundwater: Evidences from ultrafiltration and EEM-PARAFAC. Appl. Geochem. 2019, 104, 124-134. [CrossRef]

59. Broclawik, O.; Lukawska-Matuszewska, K.; Brodecka-Goluch, A.; Bolalek, J. Impact of methane occurrence on iron speciation in the sediments of the Gdansk Basin (Southern Baltic Sea). Sci. Total. Environ. 2020, 721, 137718. [CrossRef] [PubMed]

60. Zhang, Y.; Li, S.; Fang, Q.; Duan, Y.; Ou, P.; Wang, L.; Chen, Z.; Wang, F. Implementation of long-term assessment of human health risk for metal contaminated groundwater: A coupled chemical mass balance and hydrodynamics model. Ecotoxicol. Environ. Saf. 2019, 180, 95-105. [CrossRef]

61. Wang, G.; Li, J.; Sun, W.; Xue, B.; Yinglan, A.; Liu, T. Non-point source pollution risks in a drinking water protection zone based on remote sensing data embedded within a nutrient budget model. Water Res. 2019, 157, 238-246. [CrossRef]

62. Cai, K.; Song, Z. Cycling and total risks of multiple As fractions in the Beijing-Tianjin-Hebei area on the agricultural plain, China. Ecotoxicol. Environ. Saf. 2020, 190, 110097. [CrossRef]

63. Wang, X.; Xia, J.; Ding, S.; Zhang, S.; Li, M.; Shang, Z.; Lu, J.; Ding, J. Removing organic matters from reverse osmosis concentrate using advanced oxidation-biological activated carbon process combined with $\mathrm{Fe}^{3+} /$ humus-reducing bacteria. Ecotoxicol. Environ. Saf. 2020, 203, 110945. [CrossRef]

64. Li, H.; Yu, X.; Zhang, W.; Huan, Y.; Yu, J.; Zhang, Y. Risk Assessment of Groundwater Organic Pollution Using Hazard, Intrinsic Vulnerability, and Groundwater Value, Suzhou City in China. Expo. Health 2017, 10, 99-115. [CrossRef]

65. Cao, T.; Zeng, X.; Wu, J.; Wang, D.; Sun, Y.; Zhu, X.; Lin, J.; Long, Y. Groundwater contaminant source identification via Bayesian model selection and uncertainty quantification. Hydrogeol. J. 2019, 27, 2907-2918. [CrossRef]

66. Jylhä-Ollila, M.; Laine-Kaulio, H.; Niinikoski-Fusswinkel, P.; Leveinen, J.; Koivusalo, H. Water quality changes and organic matter removal using natural bank infiltration at a boreal lake in Finland. Hydrogeol. J. 2020, 28, 1343-1357. [CrossRef]

67. Ruhala, S.S.; Zarnetske, J.P.; Long, D.T.; Lee-Cullin, J.A.; Plont, S.; Wiewiora, E.R. Exploring dissolved organic carbon cycling at the stream-groundwater interface across a third-order, lowland stream network. Biogeochemistry 2017, 137, 105-126. [CrossRef]

68. Mouser, P.J.; Liu, S.; Cluff, M.A.; McHugh, M.; Lenhart, J.J.; MacRae, J.D. Redox conditions alter biodegradation rates and microbial community dynamics of hydraulic fracturing fluid organic additives in soil-groundwater microcosms. Environ. Eng. Sci. 2016, 33, 827-838. [CrossRef]

69. Sousi, M.; Liu, G.; Salinas-Rodriguez, S.G.; Chen, L.; Dusseldorp, J.; Wessels, P.; Schippers, J.C.; Kennedy, M.D.; van der Meer, W. Multi-parametric assessment of biological stability of drinking water produced from groundwater: Reverse osmosis vs. conventional treatment. Water Res. 2020, 186, 116317. [CrossRef]

70. Bai, J.; Su, X.; Wang, J.; Lyu, H.; Gao, R.; Lu, S. Multi-isotope constraints on biogeochemical processes during bank filtration: A case study of the Liao River, Northeast China. Appl. Geochem. 2020, 122, 104762. [CrossRef] 